DOI: http://doi.org/10.4038/slemaj.v19i2.11

\title{
POTENTIAL OF EXERGY EFFICIENCY IMPROVEMENT OF COAL POWER PLANTS IN SRI LANKA: A CASE STUDY
}

\author{
J.B.N.N Piyasena ${ }^{1}$, R.A Attalage ${ }^{2}$ \\ 1. Ceylon Electricity Board \\ 2. Department of Mechanical Engineering, University of Moratuwa
}

\begin{abstract}
In the context of energy utilization it is required to harvest maximum possible potential from the available energy sources. Therefore analysis, monitoring and optimization of available energy sources and in particular those related to power plants are major requirement in the sector. Generally the energy performances of power plant are evaluated using criteria based on $1^{\text {st }}$ law of thermodynamics. However, subsequent development in the field of thermodynamic studies in particular the exergy analysis was identified as a useful method to design, evaluation, optimization and improvement of power plant performance. It is based on $2^{\text {nd }}$ law of thermodynamics.
\end{abstract}

In this study, it is aimed to find out the potential of exergy efficiency improvement opportunities in coal power plants through exergy flow analysis. A methodology was developed to estimate exergy flows in coal power plants and efficiencies of major equipment in power plant employing $2^{\text {nd }}$ law or exergy analysis. This was done according to general equations which are used in thermodynamics. As a result, set of equations pertaining to the thermodynamics behaviours was established to analyse exergy flows in coal power plants.

The methodology was then applied to unit 01 of Lak Vijaya power station (LVPS) in Sri Lanka as a case study. In the process, thermodynamic properties of water-steam cycle of LVPS unit 01 under both design and actual calculation were used to evaluate exergy values of critical states of the cycle as well as the resulting exergy flows and related efficiencies of major equipment.

Boiler was identified as the major exergy destruction equipment in power plant and consequently it has less exergy efficiency.

Hence boiler sub system was analysed to identify potential of exergy efficiency improvement in coal power plants. The main parameters of boiler were used to identify the exergy flow behaviours of the boiler.

An economic analysis was also done for the boiler to identify the benefits. Not only steam generating cost saving in power plant but also reduction of hazardous $\mathrm{CO}_{2}$ emission calculations were carried out.

\section{Introduction}

Most of the power plants are designed by the energy performance criteria based on first law of thermodynamics for maximum operating efficiency. The real loss of useful energy potential cannot be evaluated by the fist law of thermodynamics, because it does not differentiate between the quality and quantity of energy.

Therefore $2^{\text {nd }}$ law of thermodynamics is used to measure the quality of energy involved in energy flows in thermodynamics systems. It is useful to identify the energy losses in systems in a proper way while evaluating exergy flows in view of estimating the useful work potential of the energy. Unlike energy, the exergy of a system would not be conserved. As energy is used in a process it loses quality and this degradation is reflected through the exergy analysis. The exergy analysis is a tool to identify losses, degradations and destruction so that appropriate measures can be taken to reduce them. An exergy analysis is a very powerful technique of optimize complex thermodynamic systems by not considering only the maximizing the $1^{\text {st }}$ law efficiency but rather optimizing the operation considering the output, losses, degradation and destruction of the potential and the quality. It could also be related to the aspect of sustainability in the overall operation.

When energy is used, some fraction simply gets converted into less useful forms, or form of less exergy thus reducing the thermodynamic potential of the source to provide maximum useful energy. The Exergy is a property associated with the state of the system and the environment. Exergy losses are additive (i.e. the total exergy loss for the system is the sum of all the component losses). Exergy is normally destroyed when a process is involved depending on the nature of the process such as level of irreversibility and operating parameters. 
This destruction is proportional to the entropy increase of the system together with its surroundings. Second law analysis is about understanding irreversibilities in systems. It focuses on changes in the quality of energy. The quality of energy is measured by exergy.

Exergy analysis helps in improving plant efficiency by determining the origin of exergy losses. Exergy helps in identifying components where high inefficiencies occur, and where improvements are merited. The thermodynamic cycle can often be optimized by minimizing the irreversibility.

Therefore the result of Exergy Analysis (2nd law thermodynamic analysis) of coal power plants can indicate the real thermodynamic losses in power generation process and could be employed to find out the improvement required area to improve the efficiency of system.

\section{Methodology}

In the absence of nuclear, magnetic, electrical, and surface tension effects, the total exergy of a system $\mathrm{E}$ can be divided into four components: physical exergy $\mathrm{E}^{\mathrm{PH}}$, kinetic exergy $\mathrm{E}^{\mathrm{KN}}$, potential exergy $\mathrm{E}^{\mathrm{PT}}$ and chemical exergy $\mathrm{E}^{\mathrm{CH}}$ [01].

$\mathrm{E}=\mathrm{E}^{\mathrm{KN}}+\mathrm{E}^{\mathrm{PT}}+\mathrm{E}^{\mathrm{PH}}+\mathrm{E}^{\mathrm{CH}}$

gZ

If we consider above equation as unit mass basis

$\mathrm{e}=\mathrm{e}^{\mathrm{KN}}+\mathrm{e}^{\mathrm{PT}}+\mathrm{e}^{\mathrm{PH}}+\mathrm{e}^{\mathrm{CH}}$

Control volume exergy rate balance is [02];

$\frac{\mathrm{dEcv}}{\mathrm{dt}}=\sum_{\mathrm{j}}\left(1-\mathrm{T}_{0} / \mathrm{T}_{\mathrm{j}}\right) \dot{\mathrm{Q}}_{\mathrm{j}}-\left(\dot{\mathrm{W}}_{\mathrm{cv}}-\frac{\mathrm{P}_{0} \mathrm{dVcv}}{\mathrm{dt}}\right)+$

(03)

$$
\sum_{\mathrm{i}} \dot{m}_{\mathrm{i}} \mathrm{e}_{\mathrm{fi}}-\sum_{\mathrm{e}} \dot{\mathrm{m}}_{\mathrm{e}} \mathrm{e}_{\mathrm{fe}}-\mathrm{E}_{\mathrm{d}}
$$

\section{Where;}

$\mathrm{e}=$ exit flow exergy

$\mathrm{i}=$ input flow exergy

The equation No.03 represent the;

$\begin{array}{cc}\text { Rateofxelgychange } & \frac{\mathrm{dEcv}}{\mathrm{dt}} \\ \text { Rateofxelgytranser= } & \sum_{\mathrm{j}}\left(1-\frac{\mathrm{T}_{0}}{\mathrm{~T}_{\mathrm{j}}}\right) \dot{\mathrm{Q}}_{\mathrm{J}}- \\ \left.\cdot{ }_{\mathrm{cv}}-\frac{\mathrm{P}_{0} \mathrm{dVcv}}{\mathrm{dt}}\right)+ \\ & \sum_{\mathrm{i}} \mathrm{m}_{\mathrm{i}} \mathrm{e}_{\mathrm{fi}}-\sum_{\mathrm{e}} \mathrm{m}_{\mathrm{e}} \mathrm{e}_{\mathrm{fe}}\end{array}$

Rateofxergydestucion $=\mathrm{E}$

d

For the Steady state form [11];

$\frac{\mathrm{dEcv}}{\mathrm{dt}}=0$
$\frac{\mathrm{dVcv}}{\mathrm{dt}}=0$
Therefore considering the No: 04 \& 05equations, equation No 03 could be modified as;

$\sum_{\mathrm{j}}\left(1-\mathrm{T}_{0} / \mathrm{T}_{\mathrm{j}}\right) \dot{\mathrm{Q}}_{\mathrm{j}}-\dot{\mathrm{W}}_{\mathrm{cv}}+\sum_{\mathrm{i}} \dot{\mathrm{m}}_{\mathrm{i}} \mathrm{e}_{\mathrm{fi}}-\sum_{\mathrm{e}} \mathrm{m}_{\mathrm{e}} \mathrm{e}_{\mathrm{fe}}-\mathrm{E}_{\mathrm{d}}=0$

Also;

$\sum_{\mathrm{j}} \mathrm{E}_{\mathrm{qj}}-\mathrm{W}_{\mathrm{cv}}+\sum_{\mathrm{i}} \mathrm{E}_{\mathrm{fi}}-\sum_{\mathrm{e}} \mathrm{E}_{\mathrm{fe}}-\mathrm{E}_{\mathrm{d}}=0$

Where;

$\dot{\mathrm{E}}_{\mathrm{qj}}=\left(1-\mathrm{T}_{0} / \mathrm{T}_{\mathrm{j}}\right) \dot{Q}_{\mathrm{j}}$

$\mathrm{E}_{\mathrm{fi}}=\mathrm{m}_{\mathrm{i}} \mathrm{e}_{\mathrm{fi}}$

$\mathrm{E}_{\mathrm{fe}}=\mathrm{m}_{\mathrm{e}} \mathrm{e}_{\mathrm{fe}}$

The above No.06 equation can express as;

$\left.\sum_{\mathrm{j}}\left(1-\mathrm{T}_{0} / \mathrm{T}_{\mathrm{j}}\right) \dot{Q}_{\mathrm{j}}-\dot{\mathrm{W}}_{\mathrm{cv}}+\sum_{\mathrm{i}} \mathrm{m}_{(\mathrm{f}} \mathrm{fi}_{\mathrm{fi}}-\mathrm{e}_{\mathrm{fe}}\right)-\mathrm{E}_{\mathrm{d}}=0$

$\left(\mathrm{e}_{\mathrm{fi}}-\mathrm{e}_{\mathrm{fe}}\right)$;

When considering the power plant analysis, it has to be considered about flow exergy, when mass flow across the boundary of control volume, there is an exergy transfer accompanying flow.

Specific flow exergy is;

$\mathrm{e}_{\mathrm{f}}=\mathrm{h}-\mathrm{h}_{0}-\mathrm{T}_{0}\left(\mathrm{~S}-\mathrm{S}_{0}\right)+\mathrm{v}^{2} / 2+\mathrm{gz}$

If we considering single inlet and exit, it can be expressed as

$\mathrm{ef}_{1}-\mathrm{ef}_{2}=\left(\mathrm{h}_{1}-\mathrm{h}_{2}\right)-\mathrm{T}_{0}\left(\mathrm{~S}_{1}-\mathrm{S}_{2}\right)+\frac{\mathrm{v}_{1}^{2}}{2}-\frac{\mathrm{v}_{2}^{2}}{2}+$

$$
\left.1-Z_{2}\right) \quad(09)
$$

Where the above kinetic and potential exergy can be represented as follows

$\mathrm{e}^{\mathrm{KE}}=\frac{\mathrm{V}^{2}}{2}$

$\mathrm{e}^{\mathrm{PE}}=\mathrm{gz}$

Physical flow exergy for simple compressible pure substances is given as

$\mathrm{e}^{\mathrm{PH}}=\mathrm{e}^{\mathrm{T}}+\mathrm{e}^{\mathrm{M}}$

Where;

$\mathrm{e}^{\mathrm{T}}$

$=$ Them altxergydependorhesysem tem prature

$\mathrm{e}^{\mathrm{M}}$

$=\mathrm{M}$ echancilxergydependonhesystem Pressure

Also physical exergy of liquid system can express as;

$\mathrm{e}^{\mathrm{PH}}=\left(\mathrm{h}-\mathrm{h}_{0}\right)-\mathrm{T}_{0}\left(\mathrm{~S}-\mathrm{S}_{0}\right)$

Also it can be expressed for gases forms as

$\mathrm{e}^{\mathrm{PH}}=\mathrm{C}_{\mathrm{p}}\left(\mathrm{T}-\mathrm{T}_{0}\right)-\mathrm{C}_{\mathrm{p}} \mathrm{T}_{0} \mathrm{~h}\left(\mathrm{~T} / \mathrm{T}{ }_{0}\right)$

Chemical exergy is the exergy component associated with the departure of the chemical composition of a system from that of environment. Standard molar chemical exergy tables are available in literature. For a hydrocarbon fuel, $\mathrm{C}_{\mathrm{a}} \mathrm{H}_{\mathrm{b}}$, standard chemical exergy tables may be used to calculate the chemical exergy values. Following equation 
could be used to find out the chemical exergy of the gaseous form of fuel.

$\overline{\mathrm{e}}_{\mathrm{ch}}=\sum \mathrm{x}_{\mathrm{n}}\left(\overline{\mathrm{e}}_{\mathrm{ch}}\right)_{\mathrm{n}}+\overline{\mathrm{RT}}_{0} \sum \mathrm{x}_{\mathrm{n}} \mathrm{h} \mathrm{x}_{\mathrm{n}}$

Where

$\mathrm{x}_{\mathrm{n}}=\mathrm{M}$ ołfradibnofithgasm xiture

$\overline{\mathrm{R}}=$ U niversaliaßonstant

But according to the references [03] the chemical exergy value of fuel is nearly equal to the HHV of that fuel.

So;

$\mathrm{e}^{\mathrm{ch}} \approx$ H H Vothafiel

Therefore by considering the exergy components explained earlier, the exergy balance could be easily expressed as;

$\sum_{\mathrm{i}=1}^{\mathrm{i}} \mathrm{E}_{\mathrm{i}}=\sum_{\mathrm{e}=1}^{\mathrm{e}} \mathrm{E}_{\mathrm{o}}+\mathrm{E}_{\mathrm{D}}$
Where;

$\mathrm{E}_{\mathrm{i}}$-Exergy input $(\mathrm{kJ} / \mathrm{s})$,

$\mathrm{E}_{\mathrm{o}}$-Exergy Output $(\mathrm{kJ} / \mathrm{s})$

$\mathrm{E}_{\mathrm{D}}-$ Exergy destruction $(\mathrm{kJ} / \mathrm{s})$

ExergyEfency $=\quad \frac{\text { U sefulExergy }}{\text { ExergySupplied }}$

Exergy Cost balance;

$\sum_{\mathrm{e}}\left(\mathrm{C}_{\mathrm{e}} \dot{\mathrm{E}}_{\mathrm{e}}\right)_{\mathrm{k}}+\mathrm{C}_{\mathrm{w}, \mathrm{k}} \dot{\mathrm{W}}_{\mathrm{k}}=\mathrm{C}_{\mathrm{q}, \mathrm{k}} \dot{\mathrm{E}}_{\mathrm{q}, \mathrm{k}}+\sum_{\mathrm{i}}\left(\mathrm{C}_{\mathrm{i}} \dot{\mathrm{E}}_{\mathrm{i}}\right)_{\mathrm{k}}+\dot{\mathrm{Z}}_{\mathrm{k}}$

$\mathrm{C}=$ Cost value $[\mathrm{LKR}]$

$\mathrm{c}=$ Unitary (specific) cost value $[\mathrm{LKR} / \mathrm{kWh}]$

$\mathrm{e}=$ Product output

$\mathrm{i}=$ Feed input

$\mathrm{k}=$ Number of component

$\mathrm{q}=$ Heat

$\mathrm{W}=$ Work

$\mathrm{W}=$ Work or power

$\mathrm{E}=$ Exergy $[\mathrm{kW}$ or $\mathrm{kJ} / \mathrm{s}]$;

Figure 1- System Flow Diagram of Subcritical Reheat Regenerative Coal Power Plant

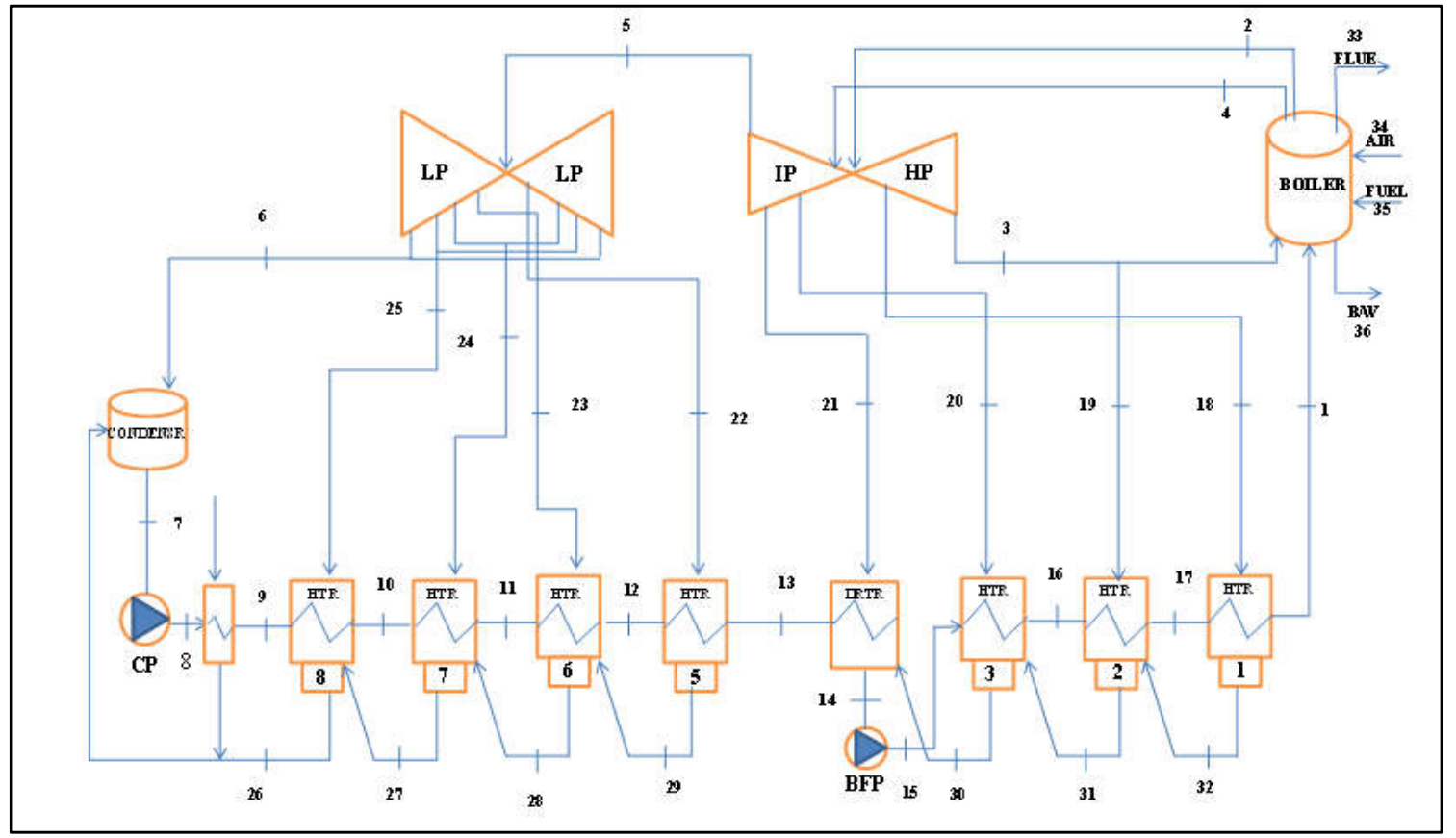

HP - High Pressure, IP- Intermediate Pressure, LP - Low Pressure, HTR- Heater, BW- Blow down water, CP - Condensate pump, BFP - Boiler Feed Pump, DRTR - Deaerator 


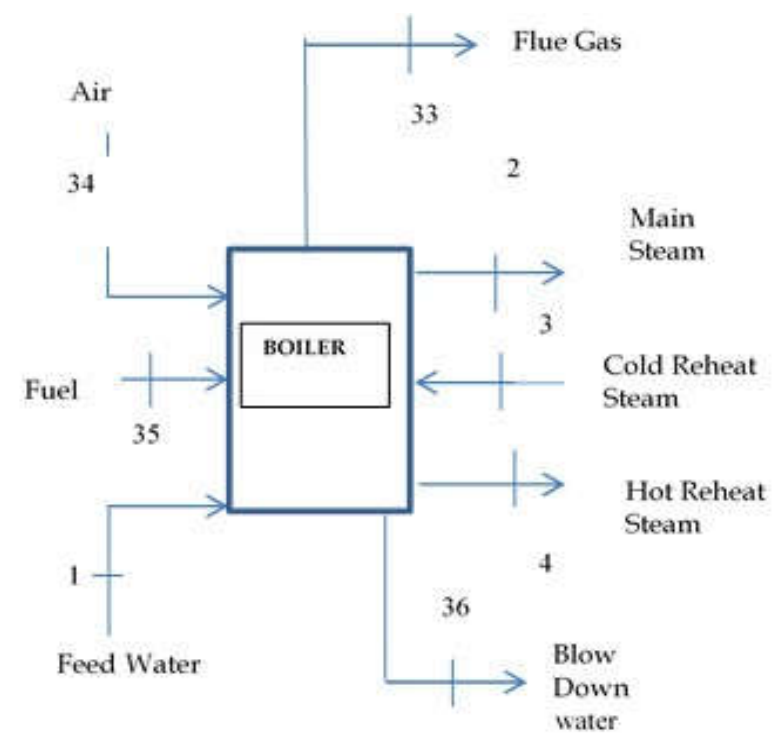

Sample Calculation

Considering input air from equation No: (14);

$$
\begin{aligned}
& \dot{\mathrm{E}}_{34}=\dot{\mathrm{m}}_{34} \mathrm{C} \mathrm{p}\left(\mathrm{T}_{34}-\mathrm{T}_{0}\right)-\mathrm{C}_{\mathrm{p}} \mathrm{T}_{0} \mathrm{~h}\left(\frac{\mathrm{T}_{34}}{\mathrm{~T}_{0}}\right) \\
& \sum_{\mathrm{i}=1}^{\mathrm{i}} \mathrm{E}_{\mathrm{i}}=\sum_{0=1}^{\mathrm{o}} \mathrm{E}_{\mathrm{o}}+\mathrm{E}_{\mathrm{D}} \\
& \text { E } \quad i=E_{34}+E_{35}+E_{1}+E_{3} \\
& \text { E o }=E_{2}+E_{4}+E_{36}+E_{33} \\
& \mathrm{E}_{34}+\mathrm{E}_{35}+\mathrm{E}_{1}+\mathrm{E}_{3} \\
& =\mathrm{E}_{2}+\mathrm{E}_{4}+\mathrm{E}_{36}+\mathrm{E}_{33}+\mathbf{E}_{\mathbf{D}}
\end{aligned}
$$

The exergy value of each component can be calculated separately. Such as $\mathrm{E}=\mathrm{E}^{\mathrm{KN}}+\mathrm{E}^{\mathrm{PT}}+\mathrm{E}^{\mathrm{PH}}+\mathrm{E}^{\mathrm{CH}}$

For some selected systems, the kinetic and potential exergy values can be neglected as those values are considerably smaller than the other components. Therefore the exergy values depend only on the physical and chemical Exergyvalues.

Chemical exergy value of supply fuel;

$\dot{\mathrm{E}}_{35} \approx \mathrm{H} H$ Voffededooal

$\mathrm{E}_{2}=\mathrm{m} \cdot\left[2\left(\mathrm{~h}_{2}-\mathrm{h}_{0}\right)-\mathrm{T}_{0}\left(\mathrm{~S}_{2}-\mathrm{S}_{0}\right)\right]$

$\mathrm{E}_{4}=\mathrm{m} \cdot\left[\mathrm{h}\left(\mathrm{h}_{4}-\mathrm{h}_{0}\right)-\mathrm{T}_{0}\left(\mathrm{~S}_{4}-\mathrm{S}_{0}\right)\right]$

$E_{36}=m_{36}\left[\left(h_{36}-h_{0}\right)-T_{0}\left(S_{36}-S_{0}\right)\right]$

Considering flue gas of boiler sub system

$$
\dot{\mathrm{E}}_{33}=\dot{\mathrm{m}}_{33}\left[\mathrm{C} \mathrm{p}\left(\mathrm{T}_{33}-\mathrm{T}_{0}\right)-\mathrm{C}_{\mathrm{p}} \mathrm{T}_{0} \mathrm{~h}\left(\frac{\mathrm{T}_{33}}{\mathrm{~T}_{0}}\right)\right]
$$

$\mathbf{E}_{\mathbf{D}_{\text {boiler }}}$

$=\left\{\dot{\mathrm{m}}_{1}\left[\left(\mathrm{~h}_{1}-\mathrm{h}_{0}\right)-\mathrm{T}_{0}\left(\mathrm{~S}_{1}-\mathrm{S}_{0}\right)\right\}\right.$

$+\left\{\dot{m}_{3}\left[\left(\mathrm{~h}_{3}-\mathrm{h}_{0}\right)-\mathrm{T}_{0}\left(\mathrm{~S}_{3}-\mathrm{S}_{0}\right)\right\}\right.$

$+\left\{\mathrm{m} \quad{ }_{34}\left[\mathrm{C}_{\mathrm{p}}\left(\mathrm{T}_{34}-\mathrm{T}_{0}\right)-\mathrm{C}_{\mathrm{p}} \mathrm{T}_{0} \mathrm{~h}\left(\frac{\mathrm{T}_{34}}{\mathrm{~T}_{0}}\right)\right]\right\}$

HH H Vofedededooal

$-\left\{\dot{m}_{2}\left[\left(h_{2}-h_{0}\right)-\mathrm{T}_{0}\left(\mathrm{~S}_{2}-\mathrm{S}_{0}\right)\right\}\right.$

$-\left\{\dot{m}_{4}\left[\left(\mathrm{~h}_{4}-\mathrm{h}_{0}\right)-\mathrm{T}_{0}\left(\mathrm{~S}_{4}-\mathrm{S}_{0}\right)\right\}\right.$

$-\left\{\mathrm{m}_{36}\left[\left(\mathrm{~h}_{36}-\mathrm{h}_{0}\right)-\mathrm{T}_{0}\left(\mathrm{~S}_{36}-\mathrm{S}_{0}\right)\right\}\right.$

$-\left\{\dot{m}_{33} C_{p}\left(T_{33}-T_{0}\right)-C_{p} T_{0} h\left(\frac{T_{33}}{T_{0}}\right)\right\}$

ExergyEfency $=\quad \frac{\text { U sefftexergy }}{\text { ExergySupped }}$

Exergy efficiency of boiler sub system;

Therefore;

$$
\mathrm{E}=\mathrm{E}^{\mathrm{PH}}+\mathrm{E}^{\mathrm{CH}}
$$

Also the chemical exergy value of some input and output components are lesser than physical exergy values. So in such conditions, only physical exergy values of that components could be considered. Therefore considering equation No: (13)

$$
\begin{aligned}
& \mathrm{E}_{1}=\left(\mathrm{h}_{1}-\mathrm{h}_{0}\right)-\mathrm{T}_{0}\left(\mathrm{~S}_{1}-\mathrm{S}_{0}\right) \\
& \mathrm{E}_{1}=\mathrm{m}\left[\left(\mathrm{h}_{1}-\mathrm{h}_{0}\right)-\mathrm{T}_{0}\left(\mathrm{~S}_{1}-\mathrm{S}_{0}\right)\right] \\
& \dot{\mathrm{E}}_{3}=\mathrm{m}\left[3\left(\mathrm{~h}_{3}-\mathrm{h}_{0}\right)-\mathrm{T}_{0}\left(\mathrm{~S}_{3}-\mathrm{S}_{0}\right)\right]
\end{aligned}
$$

$$
\begin{gathered}
\text { ExergyEfency boiler }=1-\frac{\left(E_{D}+E_{L}\right)}{E_{F u e l}} \\
\text { ExergyEfficency boiler }=1-\frac{E_{D}+E_{33}+E_{36}}{E_{34}+E_{35}+E_{1}}
\end{gathered}
$$

\section{Result and Discussion}

The figure 2 shows the design exergy destruction in major equipment in LVPS coal power plant. The boiler exergy destruction of this power plant is $435 \mathrm{MW}$. This is about $90 \%$ of total exergy destruction in the power plant. The exergy destruction values of other all-major equipment, which include turbine, pumps, condenser \& heaters, are below $10 \%$. Considering the above exergy values it can be easily identified that, the boiler is the major exergy destruction component in power plant. 
Figure 2 - Exergy Destruction Percentage of major Equipment in LVPS unit 1 for Design Conditions

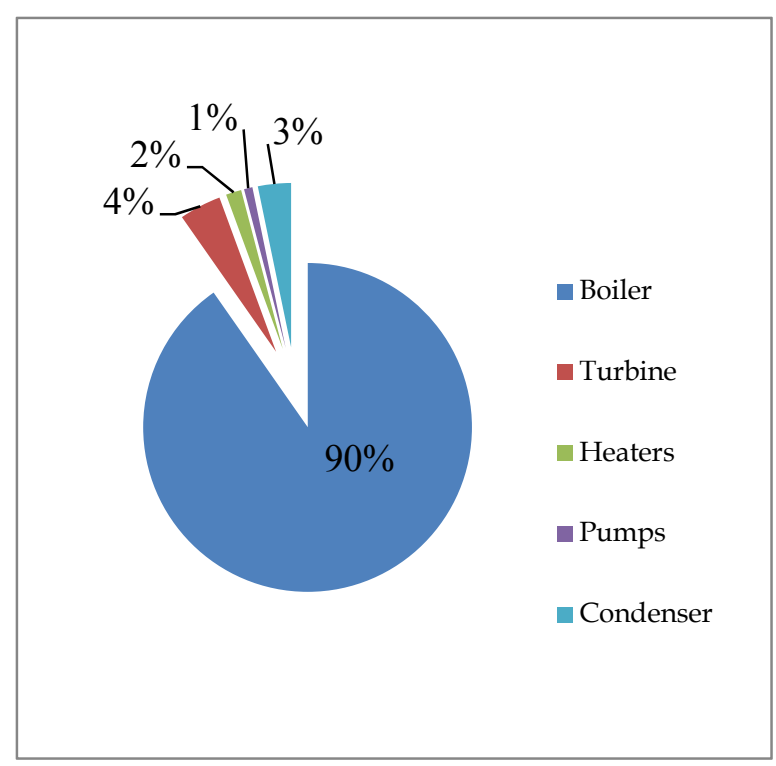

The Figure 3 shows the exergy efficiency valves in major equipment in the power plant. Except the boiler, all the other major equipment in the power plant shows more than 60\% exergy efficiency. The boiler exergy efficiency of LVPS power plant for design parameters is around $49 \%$.

Figure 3 - Exergy Efficiency of Major Equipment in LVPS for Design Conditions.

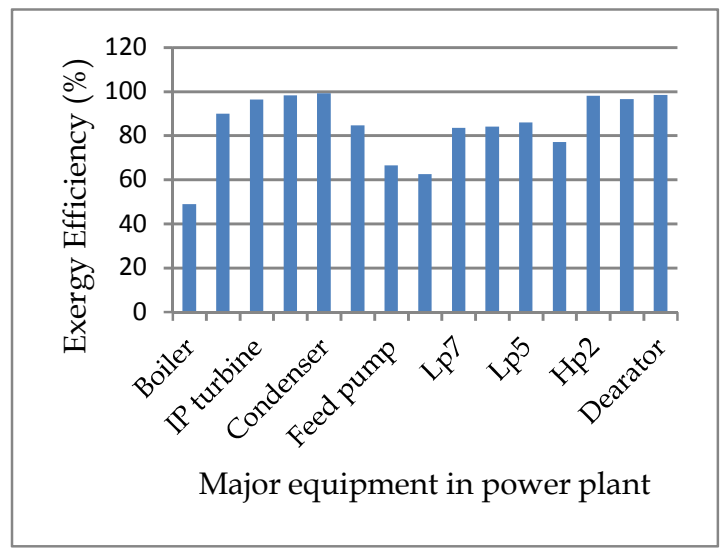

This Figure 4 shows the exergy destruction of major equipment in LVPS for operational parameters. It also displays, the major exergy destruction is occurred in boiler sub system in the power plant same as design conditions. The operational exergy destruction in the boiler is around $508 \mathrm{MW}$. This exergy destruction value is greater than the design condition and it is around $91 \%$ of total destruction of the power plant. The turbine, condenser, pumps and heaters destruction values are less than $10 \%$; it is same as design conditions.
Figure 4 -Exergy Destruction Percentage of major equipments in LVPS unit 01 for operational condition

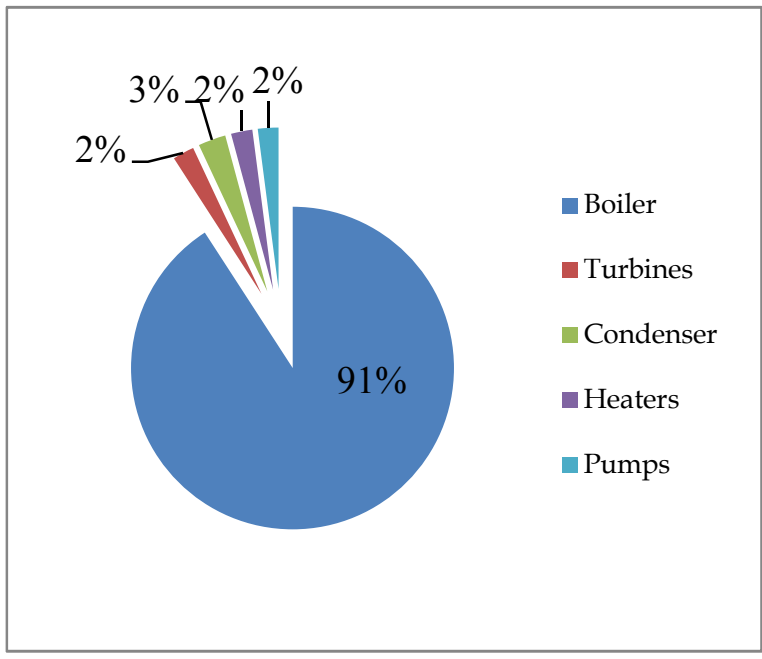

The Figure 5 shows the exergy efficiency of major equipment of LVPS power plant in actual operation conditions. The boiler exergy efficiency is around $45 \%$. This efficiency is less than the design values.

Considering all the other major equipment of the power plant it is obvious that, exergy efficiency of those items are more than $60 \%$ same as deign condition.

Figure 5 - Exergy Effiency of major equipment in LVPS for operating conditions.

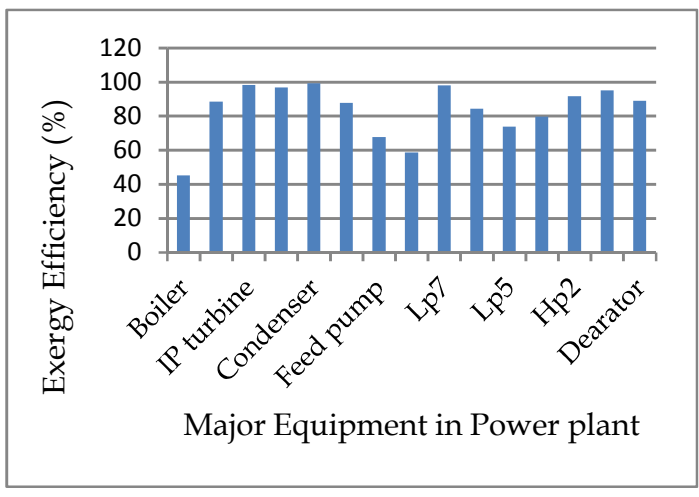


Most of the major equipment in power plant deliver lesser exergy efficiency under operation condition than design conditions. Some equipment show high exergy efficiency values than design conditions. Considering both exergy destruction and efficiency values of equipment, It was easily identified boiler as the major contributor of power plant exergy efficiency reduction process. Exergy destruction of boiler under design and operational conditions are 392 MW and 461 MW respectively. Also exergy efficiency of the boiler under design condition is $49 \%$ while $45 \%$ under operation condition. Exergy destruction of all other equipment are very much lesser than that of the boiler. Therefore boiler was identified as the major component which affects the power plant exergy performance.

Hence there is high possibility of improving power plant efficiency by reducing the exergy destruction of the boiler system.

When considering above obtained results, it is obvious that the boiler system is the major exergy destruction equipment of the power plant. Therefore, cost calculation of the power plant was done based on the boiler sub system. The fuel cost of boiler, feed water cost, capital investment and operation and maintance cost of boiler were used for the exergy cost calculation of the boiler. The unit cost of boiler main steam was obtained as LKR16.75/kWh and total exergy cost rate of boiler main steam was around LKR $6.1 \mathrm{millon} / \mathrm{h}$. Therefore reduction of boiler exergy destruction is a cricticl parameter for efficiency improvement process in the whole power plant.

\section{Identification of Exergy Efficiency Improvement Opportunities}

As explained in the previous section, it was identified the boiler as the major exergy destruction as well as less exergy efficient equipment in the power generation process of LVPS unit 01 . Therefore there is higher possibility to improve the overall exergy efficiency of the power plant by improving of the boiler exergy efficiency and reducing of exergy destruction in boiler subsystem process. Further the maximum exergy destruction in boiler system was occurred due to irreversibility in the combustion process compared to other losses.

The major heat losses are occurred in the boiler as flue gases, blow down and internal exergy destruction. Flue gas losses occurred in several ways. They are conduction, convection and radiation. Blow down water also carrying some considerable amount of heat from boiler water. Boiler blow down is an essential measure to maintain the water quality parameters in acceptable limit which prevents the boiler tube scale formation. Blow down process is done continuously and periodically based on to the boiler water quality. Heat recovery processes can be introduced to the system to recover the heat from blow down water which will improve the boiler efficiency. But the amount which can be recovered from waste heat (Blow Down water) is negligible comparing the internal exergy destruction of boiler.

Unlike energy, exergy is not conserved but destroyed by irreversibility within a system. This irreversibility may be classified as internal and external irreversibility. Main reasons of internal irreversibility are friction, unrestrained expansion, mixing and chemical reaction. External irreversibility arises due to heat transfer due to a finite temperature difference.

Therefore the reduction of internal irreversibility can be done in two ways. Redesign the boiler and improve exergy efficiency or optimize the operation condition to reduce exergy destruction of it. When considering the existing power plant it is not possible to redesign and thus the best way to improve exergy efficiency through better operating practices. When designing new power plant, it is required to consider above results and optimize the design in order to minimize the exergy destruction.

\section{Figure 6 - Type of Boiler Heat Losses in MW}

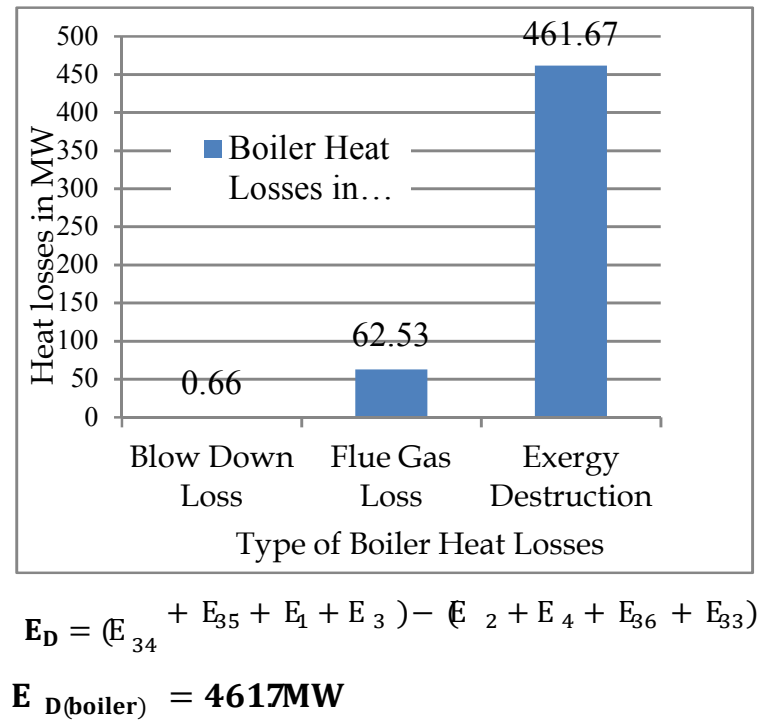


Table 1 - Exergy Input and Output Valves in Boiler sub Systems

\begin{tabular}{|l|c|c|}
\hline \multicolumn{1}{|c|}{ Component } & State & $\begin{array}{c}\text { Exergy } \\
\text { Value MW }\end{array}$ \\
\hline Air & $\mathrm{E}_{34}$ & 0.01 \\
\hline Fuel & $\mathrm{E}_{35}$ & 883.17 \\
\hline Feed Water & $\mathrm{E}_{1}$ & 73.63 \\
\hline Flue gas & $\mathrm{E}_{33}$ & 62.53 \\
\hline Main Steam & $\mathrm{E}_{2}$ & 363.07 \\
\hline Cold Reheat Steam & $\mathrm{E}_{3}$ & 207.03 \\
\hline Hot Reheat Steam & $\mathrm{E}_{4}$ & 275.90 \\
\hline Blow down water & $\mathrm{E}_{36}$ & 0.66 \\
\hline
\end{tabular}

It is required to consider some critical parameters to reduce the boiler exergy destruction. So behaviour of exergy destruction and exergy efficiency of the boiler can be obtained with the changing of critical parameters.

Those critical parameters can be identified as Plant Load, Main steam pressure, Main steam temperature, Feed water temperature and Gross calorific Value of coal. Also Load and MSP were identified as major parameters which can be directly affected to destruction and efficiency. It is required to identify the benefits which can be obtained from the improvements of exergy efficiency as value of fuel. As discussed in previous sections; the exergy cost calculation shows steam generating cost of boiler is equal to Rs.6.1million/h. for full load running conditions. As a result of exergy efficiency improvement of the boiler, fuel consumption can be reduced. This reduction of fuel consumption directly affected on the reduction of flue gas emissions also.

Figure 7 - The Variation of the Boiler Exergy Destruction and Exergy Efficiency with Plant Load under Operation Condition.

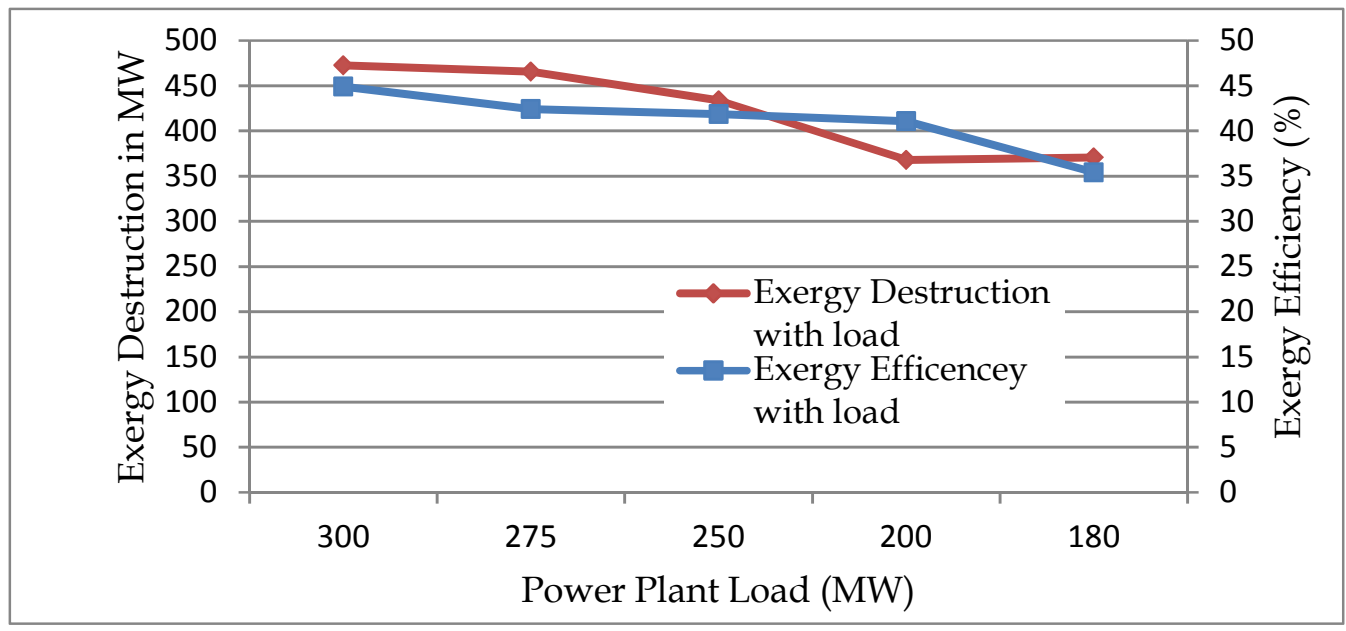

Figure 8 - The Variation of Boiler Exergy Efficiency and Exergy Destruction with Main Steam Pressure under rated Load Condition

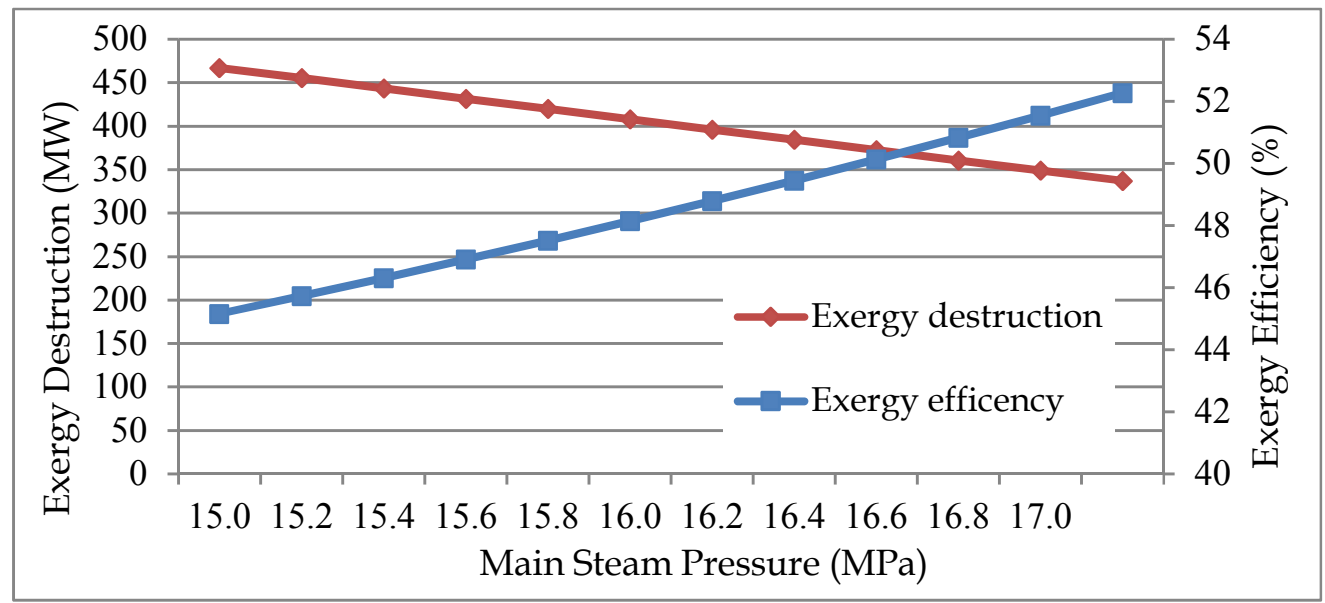


Figure 9 - The Variation of Boiler Steam Generating Cost with Boiler Exergy Efficiency

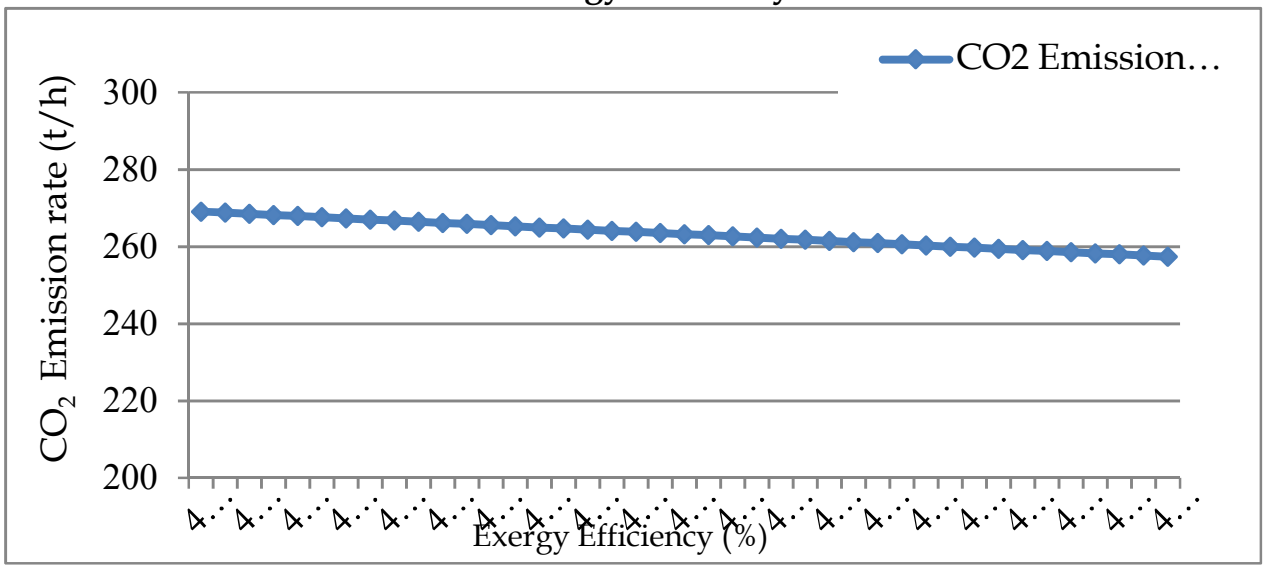

Figure 10 - The Variation of $\mathrm{CO}_{2}$ Emission with Boiler Exergy Efficiency

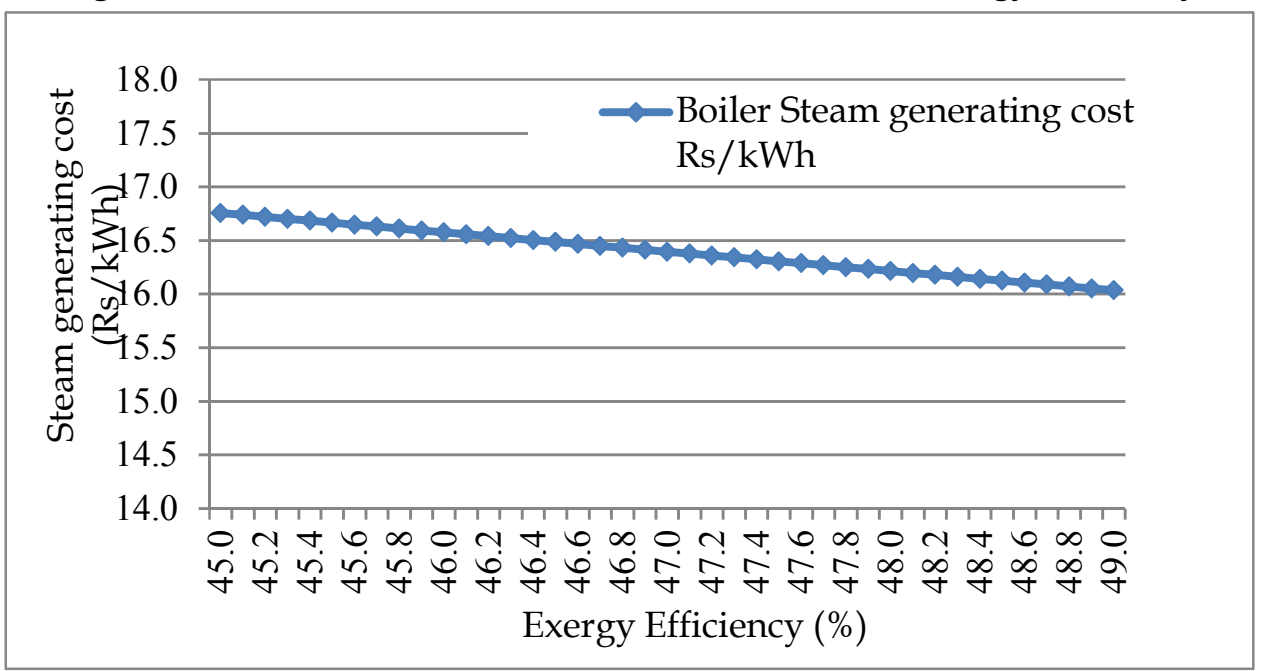

\section{Conclusion}

Potential of exergy efficiency improvement in coal power plant is directly related to reduction of exergy destruction in overall power plant. The boiler sub system is the major contributor of overall exergy destruction in the coal power plant. Therefore worthy exergy efficiency improvements of overall power plant can be achieved by reducing of destruction of exergy of the boiler. Hence proper consideration shall be given to above discussed boiler parameters to improve its exergy efficiency. As a result overall efficiency of the coal power plant can be improved.

Coal power plant shall be operated under its rated load condition as base load plant as much as possible. Also the main steam pressure of the boiler shall be maintained at maximum working pressure in order to improve the overall exergy efficiency of the power plant.
According to the results obtained, it is required to operate Unit 01 of LVPS at its rated capacity of $300 \mathrm{MW}$ and boiler main steam pressure around 16MPa to improve the overall efficiency of the power plant.

\section{References}

[01] S.C. Kaushika, V.SivaReddya, S.K.Tyagib. "Energy and exergy analyses of thermal power plants" Renewable and Sustainable Energy Reviews. [online]. pp 18571872.Internet: www.elsevier.com/locate/rser

[02] M.J Moran, H.N Shapiro. "Exergy Analysis" in Fundamental of Engineering Thermodynamics, 5th Edition, John Wiley \& Sons Ltd, The Atrium, Southern Gate, Chichester. pp. 272-312

[03] T.Kotas. "Basic Exergy Concept" The Exergy Method in Thermal plant Analysis, Krieger publishing company, Florida,(1995), pp 44-45 